\title{
Close Association between Interleukin 2 Receptor mRNA Expression and Human T Cell Leukemia/Lymphoma Virus Type I Viral RNA Expression in Short- term Cultured Leukemic Cells from Adult T Cell Leukemia Patients
}

\author{
Hiroshi Umadome, Takashi Uchiyama, Toshiyuki Hori, Shigeki Tamori, Tomomi Motoi, Koichi Araki, and Haruto Uchino \\ The First Division of Internal Medicine, Faculty of Medicine, Kyoto University, Kyoto, Japan; The Second Division \\ of Internal Medicine, School of Medicine, University of the Ryukyu, Okinawa, Japan
}

\begin{abstract}
Human T cell leukemia/lymphoma (T-lymphotropic) virus type I (HTLV-I) infection has been considered to be closely associated with the leukemogenesis of adult $T$ cell leukemia (ATL), in which interleukin 2 (IL-2) receptors are abnormally expressed. In this study, however, Southern blot analysis revealed no gross rearrangement or obvious amplification of the IL-2 receptor gene in ATL leukemic cells, indicating that abnormal IL-2 receptor expression in ATL is not due to the structural change of its gene. Hence, we studied the expression of the IL-2 receptor and HTLV-I at the RNA level during short-term cultures of leukemic cells from 9 ATL patients. Cytoplasmic dot hybridization and Northern hybridization revealed that fresh leukemic cells from seven of nine patients expressed a small amount of IL-2 receptor mRNA but HTLVI RNA was undetectable in all cases. After cultures for up to 7 d, both IL-2 receptor $m R N A$ and HTLV-I RNA (including $p X$ message) expression concomitantly increased, whereas the amounts of other cellular genes, except for $\beta$-actin, did not. The increases in their RNA expression were inhibited by early addition (within $12 \mathrm{~h}$ after the beginning of the culture) of cycloheximide, indicating that these increases are mediated by newly synthesized protein(s). These results strongly suggested that IL-2 receptor expression is closely associated with HTLV-I expression in leukemic cells from ATL patients.
\end{abstract}

\section{Introduction}

Human T cell leukemia/lymphoma virus type I (human Tlymphotropic retrovirus type I; HTLV-I $)^{1}$ was first discovered in a $\mathrm{T}$ cell line derived from an American patient with an

Address reprint requests to Dr. Uchiyama, The First Division of Internal Medicine, Faculty of Medicine, Kyoto University, 54 ShogoinKawaramachi, Sakyo, Kyoto, 606, Japan.

Received for publication 17 June 1986 and in revised form 2 June 1987.

1. Abbreviations used in this paper: ADF, ATL-derived factor; ATL, adult T cell leukemia; ATLA, ATL-associated antigen; HPRT, hypoxanthine-guanine phosphoribosyl transferase; HTLV-I, human T cell leukemia/lymphoma virus type I; LTR, long terminal repeat; STLV, simian T cell leukemia virus; TPA, 12-O-tetradecanoylphorbol-13-acetate.

J. Clin. Invest.

(c) The American Society for Clinical Investigation, Inc.

$0021-9738 / 88 / 01 / 0052 / 10 \$ 2.00$

Volume 81, January 1988, 52-61 aggressive type of cutaneous T cell lymphoma (1). Identification of the same type of virus $(2,3)$ independently found and isolated $(4,5)$ from a cell line derived from a Japanese adult $T$ cell leukemia (ATL) patient (6), and subsequent serological (7-9) and virological (10) studies indicate that HTLV-I infection is closely associated with the leukemogenesis of ATL. Recent studies $(11,12)$ demonstrating the transcriptional transactivation of the HTLV-I long terminal repeat (LTR) by $p X$ region product(s) suggest that it plays a role in viral replication and possibly in transformation of $T$ cells by transactivation of the cellular gene(s), which is directly or indirectly involved in the cell growth.

The proliferation of the peripheral mature $\mathrm{T}$ cells initiated by the stimulation of $\mathrm{T}$ cell receptor/T 3 complex is controlled mainly by the regulation of the production of interleukin 2 (IL-2) and the expression of its receptor $(13,14)$. Since the demonstration of Tac antigen (IL-2 receptor) on leukemic cells from ATL patients (15), we have reported the spontaneous and continuous ("constitutive") expression and some abnormal features of IL-2 receptors in ATL (16-18), and proposed the hypothesis that abnormally expressed IL-2 receptors induced by HTLV-I infection play a key role in the leukemogenesis of ATL.

The association of HTLV-I infection and IL-2 receptor expression has been suggested from the following observations: peripheral blood leukemic cells from ATL patients express IL-2 receptors $(15,18)$; HTLV-I-infected cell line cells express an enhanced number of IL-2 receptors (19); HTLV-I-infected rat $\mathrm{T}$ cell lines and STLY (an analogous virus of HTLV-I in a monkey)-infected cell lines express IL-2 receptors of each species $(20,21)$. However, fresh peripheral blood leukemic cells do not express HTLV-I viral antigen (22) or RNA (23) in most cases. In addition, analyses of the HTLV-I proviral integration site and the rearrangement of $T$ cell receptor $\beta$-chain gene demonstrated that most cell lines cultured from ATL patients are not the same clone as the leukemic cell clone (24-26). In this context, it is important to study the relation of HTLV-I and IL-2 receptor expression in leukemic cells from ATL patients but not cell lines.

In this paper we first performed Southern blot analysis of the IL-2 receptor gene of leukemic cells from ATL patients to see whether constitutive IL-2 receptor expression in ATL is due to its structural changes. As no such abnormalities were found, we next studied simultaneously both HTLV-I and IL-2 receptor expression at the RNA level, taking the advantage of the enhancement of cell surface IL-2 receptor expression in short-term cultured leukemic cells. And we will show the concomitant enhancement of HTLV-I viral RNA and IL-2 receptor mRNA expression during short-term cultures of peripheral blood leukemic cells from ATL patients. 


\section{Methods}

Patients and diagnosis. Nine patients with ATL were studied (Table I). Their ages ranged from 25 to $78 \mathrm{yr}$, and five of them were male. The diagnosis of ATL was made by clinical features (6), morphological characteristics (6), cell surface phenotypes of leukemic cells (15), serum antibodies to ATL-associated antigens (ATLA) (4), and the HTLV-I proviral integration (10) in DNA of leukemic cells. Peripheral white blood cell count ranged from 35,000 to $249,000 / \mathrm{mm}^{3}$.

Cell separation and culture. Peripheral blood mononuclear cells were separated from heparinized blood by Ficoll-Conray density gradient centrifugation. Leukemic cells were cultured in RPMI 1640 medium (Nissui Pharmaceutical Co., Ltd., Tokyo, Japan) supplemented with $10 \%$ FCS (Gibco, Grand Island, NY), and $20 \mu \mathrm{g} / \mathrm{ml}$ gentamicin or tobramycin for 3-8 d. Normal peripheral blood mononuclear cells without cultivation and those cultured with $0.1 \%$ phytohemagglutinin-P (PHA-P) (Difco Laboratories, Detroit, MI) or with $0.1 \%$ PHA-P and $10 \mathrm{ng} / \mathrm{ml} \mathrm{12-O-tetradecanoylphorbol-13-acetate} \mathrm{(TPA)}$ (Sigma Chemical Co., St. Louis, MO) for $20 \mathrm{~h}$ were used as controls. HTLV-I-infected Hut 102 and MT-1 (kindly provided by Dr. I. Miyoshi, Kochi Medical School, Kochi, Japan) cell lines and HTLV-I-uninfected HPB-ALL and HL-60 cell lines were maintained in RPMI 1640 medium containing 10\% FCS. To examine the effect of cycloheximide, leukemic cells were cultured with $10 \mu \mathrm{g} / \mathrm{ml}$ cycloheximide (Sigma Chemical Co.).

Flow cytometric detection of $I L-2$ receptors. IL-2 receptors expressed on leukemic cells before and after cultures for $2 \mathrm{~d}$ were detected by flow cytometric analysis after indirect immunofluorescence staining with anti-Tac monoclonal antibody $(27,28)$ as described previously (18).

Radiolabeled anti-Tac antibody binding assay. Radiolabeled antiTac antibody binding assay was performed as described previously (18) to measure the total number of IL-2 receptors.

Cytoplasmic dot hybridization. Cytoplasmic dot hybridization was performed according to the method described by White et al. (29). In brief, $5 \times 10^{6}$ cells were lysed by adding $0.5 \%$ Nonidet P-40 (Nakarai Chemicals, Kyoto, Japan) in the presence of $10 \mathrm{mM}$ Vanadyl ribonucleoside complex (Bethesda Research Laboratories Life Technologies Inc., Bethesda, MD). After pelleting of the nuclei, the supernatant was incubated with $7.4 \%$ formaldehyde and $6 \times$ standard saline citrate (SSC; $0.15 \mathrm{M} \mathrm{NaCl}, 0.015 \mathrm{M}$ trisodium citrate) at $60^{\circ} \mathrm{C}$ for $15 \mathrm{~min}$. The samples serially diluted with $15 \times$ SSC were then applied with suction to a 4-mm diam spot on nitrocellulose filters (Schleicher \& Schuell, Dassel, FRG) employing a 96-hole apparatus (Minifold; Schleicher \& Schuell) starting with cytoplasmic extracts derived from 0.4 million cells with twofold serial dilution. The nitrocellulose filters were baked at $75^{\circ} \mathrm{C}$ for $6 \mathrm{~h}$. After prehybridization, the filters were hybridized at $65^{\circ} \mathrm{C}$ for $14-18 \mathrm{~h}$ with ${ }^{32} \mathrm{P}$-labeled probes in hybridization buffer containing $1 \times$ modified Denhardt's solution, $1 \mathrm{M} \mathrm{NaCl}, 50$

Table I. Patients with ATL

\begin{tabular}{llllll}
\hline Case & Age & Sex & WBC & $\begin{array}{l}\text { Anti-ATLA } \\
\text { antibody }\end{array}$ & $\begin{array}{l}\text { HTLV-I } \\
\text { provirus }\end{array}$ \\
\hline & & & per $\mathrm{mm}^{3}$ & & \\
M.S. & 24 & M & 38,000 & + & + \\
S.Yo. & 59 & M & 47,000 & + & + \\
S.Ya. & 54 & F & 48,000 & + & + \\
Y.S. & 35 & M & 249,000 & + & + \\
S.H. & 64 & F & 67,000 & + & + \\
T.O. & 52 & M & 116,000 & + & + \\
Y.T. & 66 & F & 35,000 & + & + \\
K.K. & 49 & F & 44,000 & + & + \\
F.N. & 78 & M & 38,000 & + & + \\
& & & & & +
\end{tabular}

$\mathrm{mM}$ Tris-HCl pH 7.4, $10 \mathrm{mM}$ EDTA, $0.1 \%$ SDS, $50 \mu \mathrm{g} / \mathrm{ml}$ denatured salmon sperm DNA (30), and washed first in $2 \times$ SSC, $0.1 \%$ SDS at room temperature for $30 \mathrm{~min}$, then three times in $0.1 \times$ SSC, $0.1 \%$ SDS at $45^{\circ} \mathrm{C}$ for $30 \mathrm{~min}$. The exposure to x-ray films (RXO; Fuji Film Co., Tokyo, Japan) was done at $-70^{\circ} \mathrm{C}$ with an intensifying screen (Grenex G8; Fuji Film Co.).

Southern blot hybridization. High-molecular weight DNA was prepared as follows; $1 \times 10^{7}$ cells were suspended in $50 \mathrm{mM}$ Tris- $\mathrm{HCl} \mathrm{pH}$ 8.0, $10 \mathrm{mM}$ EDTA, $0.15 \mathrm{M} \mathrm{NaCl}$, lysed by adding $0.3 \%$ SDS and $0.5 \mathrm{M}$ $\mathrm{NaClO}_{4}$, extracted with 0.5 volume each of water-saturated phenol and a chloroform-isoamyl alcohol mixture (24:1). The water phase was separated by centrifugation and extracted with an equal volume of a chloroform-isoamyl alcohol mixture. After centrifugation the water phase was collected and extensively dialyzed against $0.1 \times$ SSC. $5 \mu \mathrm{g}$ of DNA extracted from each sample were digested with the appropriate restriction endonucleases (Eco RI or Bam $\mathrm{HI}$ ) (Toyobo Co., Ltd.; Osaka, Japan), electrophoresed in a $\mathbf{0 . 7 \%}$ agarose gel, transferred to a nitrocellulose filter and baked (31). Hybridization, washing, and autoradiography were performed as described for cytoplasmic dot hybridization except washing at $65^{\circ} \mathrm{C}$.

Northern blot hybridization. Total cellular RNA was purified by guanidine isothiocyanate solubilization (32) followed by centrifugation through cesium chloride (33). Total RNA $(20 \mu \mathrm{g})$ was incubated in $1 \mathrm{M}$ glyoxal, $50 \%$ (vol/vol) dimethyl sulfoxide, $10 \mathrm{mM}$ sodium phosphate buffer pH 7.0 at $50^{\circ} \mathrm{C}$ for $60 \mathrm{~min}$ (34), electrophoresed in $1 \%$ agarose gel, transferred to a nitrocellulose filter, and baked. Hybridization, washing, and autoradiography were performed as described for cytoplasmic dot hybridization.

Probes. Tac-2 clone and Sau 3A fragment of IL-2 receptor cDNA described elsewhere (35) were used for DNA and RNA analysis, respectively. For the analysis of HTLV-I viral RNA expression, Acc I-Sma I fragment ( 961 base pairs [bp]) of $p X$ region containing $p X$ II-IV (36) generously provided by Dr. T. Honjo (Kyoto University, Kyoto) was used. A 2.6-kb Hind III-Eco RI fragment of the human T cell receptor $\beta$-chain gene containing constant region of the human $\beta$-chain generously provided by Dr. T. Honjo (Kyoto University) (37), Hinf I fragment of pIL-2-50A generously provided by Dr. T. Taniguchi (Osaka University, Osaka) (38), Bam HI-Pvu II fragment of the human pseudo- $\beta$-actin gene generously provided by Dr. T. Kakunaga (Osaka University, Osaka), $1.5 \mathrm{~kb}$ Sst I fragment of the human c-myc protooncogene that carries the second myc exon (Amersham Japan, Tokyo), Pst I-Hind III fragment of mouse hypoxanthine-guanine phosphoribosyl transferase (HPRT) cDNA kindly supplied by Dr. C. T. Caskey (39) through Japanese Cancer Research Resources Bank, and $E c o$ RI fragment of the mouse rRNA gene generously provided by Dr. R. Kominami (Tokyo University, Tokyo) were also used as probes. These probes were nick-translated (40) using $\alpha-\left[{ }^{32} \mathrm{P}\right] \mathrm{dCTP}(3,000 \mathrm{Ci} /$ $\mathrm{mmol}$ ) (Amersham Japan). Specific activity of the probes was $200-1200 \mathrm{cpm} / \mathrm{pg}$.

\section{Results}

Expression of $I L-2$ receptors on fresh and cultured $A T L$ leukemic cells. More than $5 \%$ of the peripheral blood leukemic cells from 8 of 9 patients with ATL examined expressed IL-2 receptors on their cell surface when stained with anti-Tac antibody. When examined after $2 \mathrm{~d}$ in culture, the proportion of $\mathrm{Tac}(+)$ cells and the mean fluorescence intensity were higher than those of fresh leukemic cells, indicating the enhancement of IL-2 receptor expression during cultures (Table II).

Radiolabeled anti-Tac antibody binding assay. In two patients, we studied the enhancement of IL-2 receptor expression after short-term cultures of ATL leukemic cells by radiolabeled anti-Tac antibody binding assay. Fresh peripheral blood leukemic cells from the two patients expressed 2,200 and 2,800 anti-Tac binding sites per cell. After cultures for $2 \mathrm{~d}$ they ex- 
Table II. Expression of IL-2 Receptors in Fresh and Cultured ATL Leukemic Cells

\begin{tabular}{lrrrrr} 
& \multicolumn{2}{l}{ Fresh } & & \multicolumn{2}{l}{ Cultured* } \\
\cline { 2 - 3 } \cline { 5 - 6 } Case & Positive & MFI $^{*}$ & & Positive & MFI \\
\hline & $\%$ & & $\%$ & \\
M.S. & 36.6 & 19.2 & & 68.0 & 50.4 \\
S.Yo. & 12.6 & 10.1 & & 25.3 & 52.4 \\
S.Ya. & 52.2 & 16.1 & & 84.0 & 76.8 \\
Y.S. & 19.5 & 7.9 & & 45.1 & 42.4 \\
S.H. & 9.9 & 5.5 & & 31.7 & 9.7 \\
T.O. & 18.0 & 10.8 & 63.0 & 29.1 \\
Y.T. & 2.2 & 3.6 & & 9.1 & 5.8 \\
K.K. & 47.0 & 21.7 & 58.8 & 50.2 \\
F.N. & 9.6 & 9.6 & ND & ND \\
& & & & \\
\hline
\end{tabular}

* Leukemic cells were cultured for $2 \mathrm{~d}$ in medium alone.

‡ MFI; mean fluorescence intensity of total cells examined.

pressed more anti-Tac binding sites $(14,000$ and 8,800 , respectively).

Southern blot analysis of the IL-2 receptor gene in ATL leukemic cells. Southern blot analysis was performed on peripheral blood leukemic cells from seven ATL patients and lymph node cells from one patient to see whether leukemic cells, expressing IL-2 receptor constitutively, have some structural changes in the IL-2 receptor gene. Tac- 2 probe hybridized with five Eco RI fragments (Fig. 1) and two Bam HI fragments (data not shown) of high-molecular weight DNA from peripheral blood leukemic cells of ATL patients and an HTLV-I-infected cell line (MT-1) as well as from normal peripheral blood lymphocytes. No obvious difference in the pattern or intensity of bands was detectable, indicating neither gross rearrangement nor apparent amplification of the IL-2 receptor gene in ATL leukemic cells.

$I L-2$ receptor $m R N A$ expression in fresh and cultured leukemic cells. To determine whether the enhancement of IL-2 receptor expression after short-term cultures is associated with the increase of IL-2 receptor mRNA, the expression of IL-2 receptor mRNA in fresh and cultured leukemic cells was studied using a cytoplasmic dot hybridization.

Data of three representative cases dre shown in Figs. $2 A, 3$ $A$, and $4 A$. In case M.S. (Fig. $2 A$ ), fresh leukemic cells expressed a small amount of IL-2 receptor mRNA, which was about $1 / 2^{4}$ that of Hut 102 cells. When the cytoplasmic extracts obtained after the cultivation of the leukemic cells were examined, the expression of IL-2 receptor mRNA increased gradually, reached a peak on the fourth day, and then slightly decreased on the seventh day. The maximal amount of IL-2 receptor mRNA expressed was twice that of Hut 102 cells. In case Y.S. (Fig. $3 A$ ), fresh cells scarcely expressed IL-2 receptor mRNA, but after culture for $1 \mathrm{~d}$ a large quantity of IL-2 receptor mRNA was expressed. The maximal expression was comparable to that of Hut 102 cells. In contrast, fresh leukemic cells from patient Y.T. (Fig. $4 A$ ) expressed virtually no IL-2 receptor mRNA. In addition, the increase of its expression during short-term cultures was slight and the maximal amount of IL-2 receptor mRNA was much less than that of Hut 102 cells. The patterns of the increase of IL-2 receptor
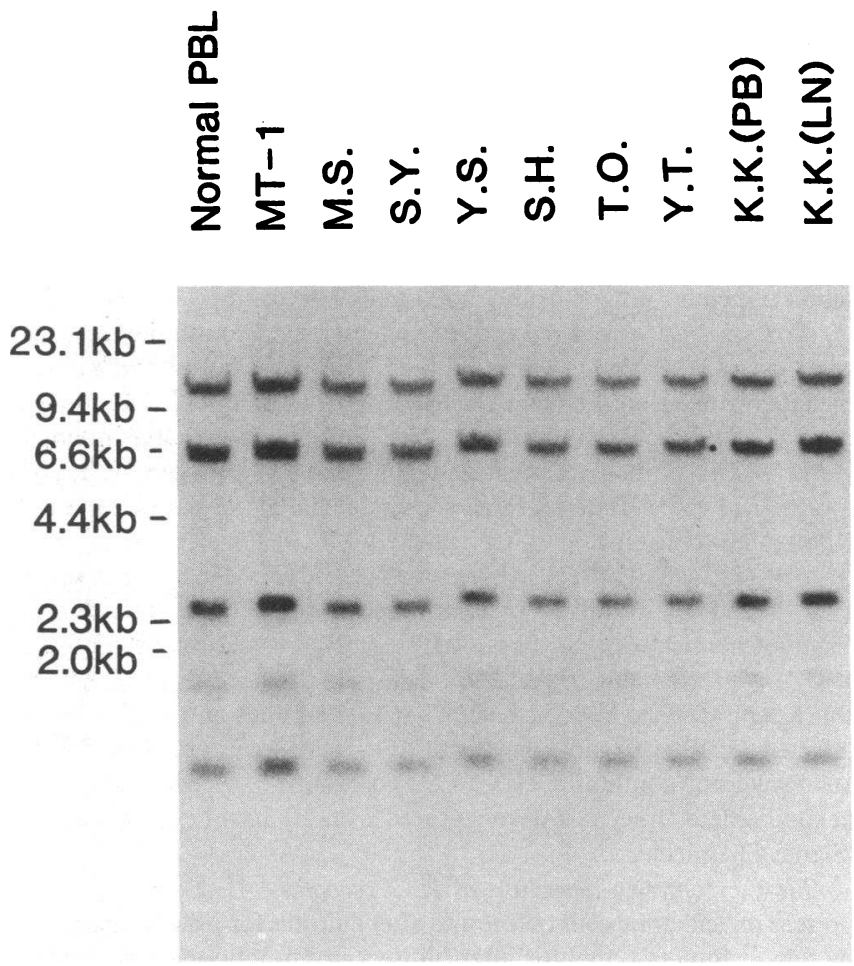

Figure 1. Southern blot analysis of the IL-2 receptor gene in ATL leukemic cells. High-molecular weight DNA was prepared from peripheral blood leukemic cells of the indicated patient. In case K.K. both lymph node cells $(L N)$ and peripheral blood leukemic cells $(P B)$ were analyzed. DNA $(5 \mu \mathrm{g})$ from each sample was digested with restriction enzyme $E c o$ RI and loaded to each lane. After electrophoresis and transfer to a nitrocellulose filter, hybridization using Tac-2 probe was performed.

mRNA expression in the remaining ATL cases examined were similar to these three representative cases.

The characteristics of the IL-2 receptor mRNA expression in the nine ATL cases were: In fresh leukemic cells, the expression of IL-2 receptor mRNA was detectable in seven of nine patients and it varied from virtually no expression to $1 / 2^{4}$ that of Hut 102 cells. After short-term cultures, the amount of IL-2 receptor mRNA per cell increased although the degree and the rate of its increase varied.

In cytoplasmic dot hybridization studies, the quantity of IL-2 receptor mRNA per cell was measured. In addition, the contents of IL-2 receptor mRNA per total cellular RNA were examined by Northern blot analysis (Fig. $5 \mathrm{~A}$ ). Two species of IL-2 receptor mRNA, 3.5 and $1.5 \mathrm{~kb}$, were detected as reported previously $(35,41)$. In case M.S. fresh leukemic cells expressed a small amount of IL-2 receptor mRNA but cultured cells expressed much more IL-2 receptor mRNA. Similarly, a remarkable increase of IL-2 receptor mRNA was detected in case Y.S. though fresh cells scarcely expressed IL-2 receptor mRNA.

HTLV-I viral RNA expression in fresh and cultured leukemic cells. We next examined the expression of HTLV-I viral RNA using the filters prepared from the same samples as IL-2 receptor mRNA studies. Figs. $2 B, 3 B$, and $4 B$ show the HTLV-I viral RNA expression in three ATL cases in which IL-2 receptor mRNA expression has been described above. In contrast to virtually no viral RNA expression in fresh leukemic 

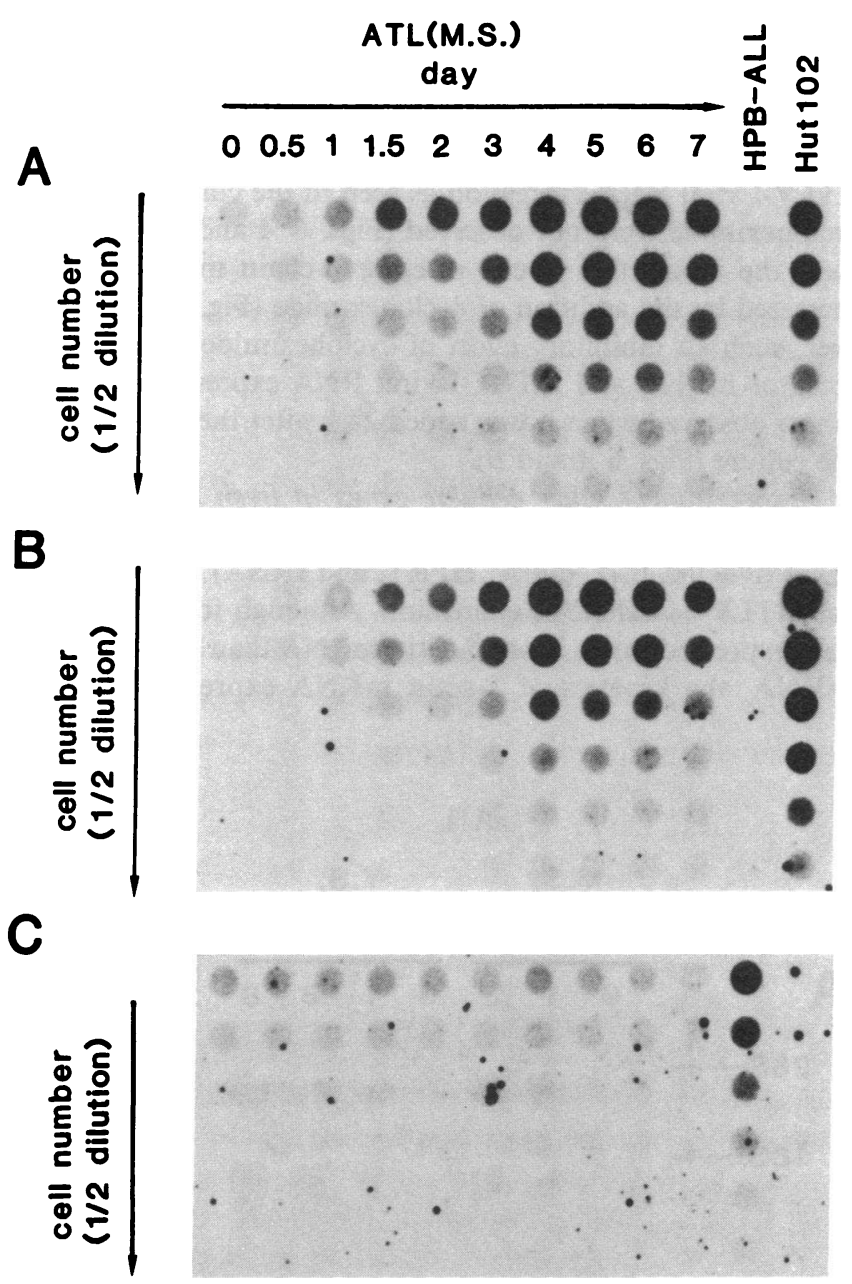

Figure 2. Expression of IL-2 receptor mRNA, HTLV-I viral RNA, and $T$ cell receptor $\beta$-chain mRNA in case MS. Leukemic cells were harvested on the indicated day after short-term cultures. Cytoplasmic extracts were prepared from fresh and cultured cells and spotted onto nitrocellulose filters in vertical rows using twofold serial dilutions. Cytoplasmic extracts derived from $4 \times 10^{5}$ cells were applied to the uppermost spot of each vertical row. Each filter was hybridized with probes for IL-2 receptor $(A)$, HTLV-I $(B)$, and T cell receptor $\beta$-chain $(C)$. HPB-ALL and Hut 102 cells were treated and spotted onto each filter in the same manner.

cells, cultured cells expressed a clearly detectable amount of viral RNA although the degree and the rate of increase in viral RNA content during short-term cultures varied. In case M.S. (Fig. $2 B$ ), viral RNA expression increased gradually, reached a peak on the fourth day and then slightly decreased. The maximal amount of viral RNA expressed during cultures was a half of that of Hut 102 cells, which were reported to continuously produce HTLV-I particles. Leukemic cells from case Y.S. (Fig. $3 B$ ) required 1-d culture to express a large amount of viral RNA. The maximal amount of viral RNA they expressed was comparable to that of Hut 102 cells. In case Y.T. (Fig. 4 B), leukemic cells expressed slight viral RNA even after cultivation. The pattern of the increase of HTLV-I viral RNA expression was similar to that of IL-2 receptor mRNA expression in every case we examined.

In Northern blot analysis three major species of RNA (8.5, 4.2 , and $2.1 \mathrm{~kb}$ ) were detected (Fig. $5 \mathrm{~B}$ ), which represent genomic RNA, mRNA of env, and mRNA of $p X$, respectively (42). Fresh leukemic cells expressed no detectable band of viral RNA but cultured cells expressed a large amount of viral RNA including $p X$ message.

Expression of $T$ cell receptor $\beta$-chain $m R N A$ in fresh and cultured leukemic cells. T cell receptor $\beta$-chain mRNA expression was simultaneously examined in fresh and cultured leukemic cells from ATL patients. As shown in Fig. $2 C$, the level of $\mathrm{T}$ cell receptor $\beta$-chain mRNA expression of leukemic cells from patient M.S., unlike IL-2 receptor mRNA or HTLV-I viral RNA expression, was not markedly altered during cultures in cytoplasmic dot analysis. The same result was also obtained in Northern blot analysis, where ATL leukemic cells expressed two species of $\mathrm{T}$ cell receptor $\beta$-chain mRNA with

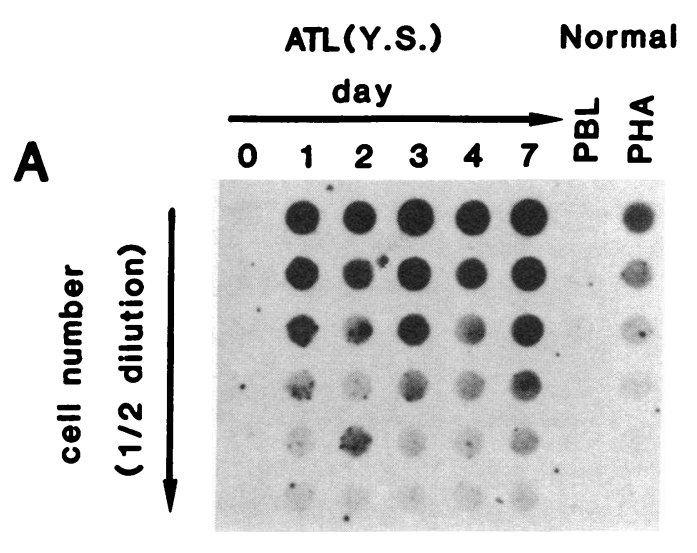

B
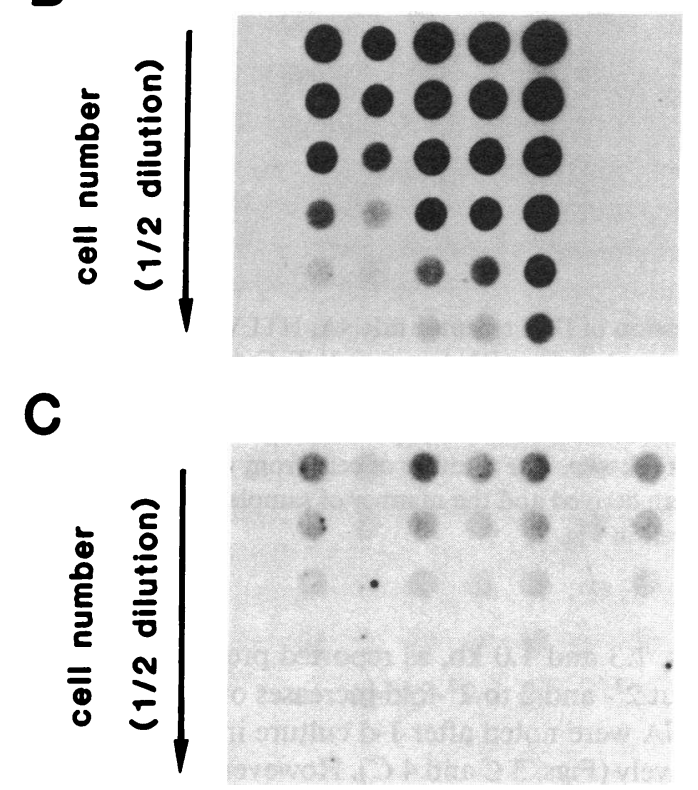

Figure 3. Expression of IL-2 receptor mRNA, HTLV-I viral RNA and T cell receptor $\beta$-chain mRNA in case Y.S. Cytoplasmic dot analyses of IL-2 receptor mRNA $(A)$, HTLV-I viral RNA $(B)$ and T cell receptor $\beta$-chain mRNA $(C)$ expression before and after short-term cultures are shown. The number of cells from which the cytoplasmic extracts were derived and the manner of sample dilutions are the same as described in Fig. 2. Data of fresh and PHA-stimulated peripheral blood mononuclear cells instead of HPB-ALL and Hut 102 cells are shown, indicated as PBL and PHA, respectively. 

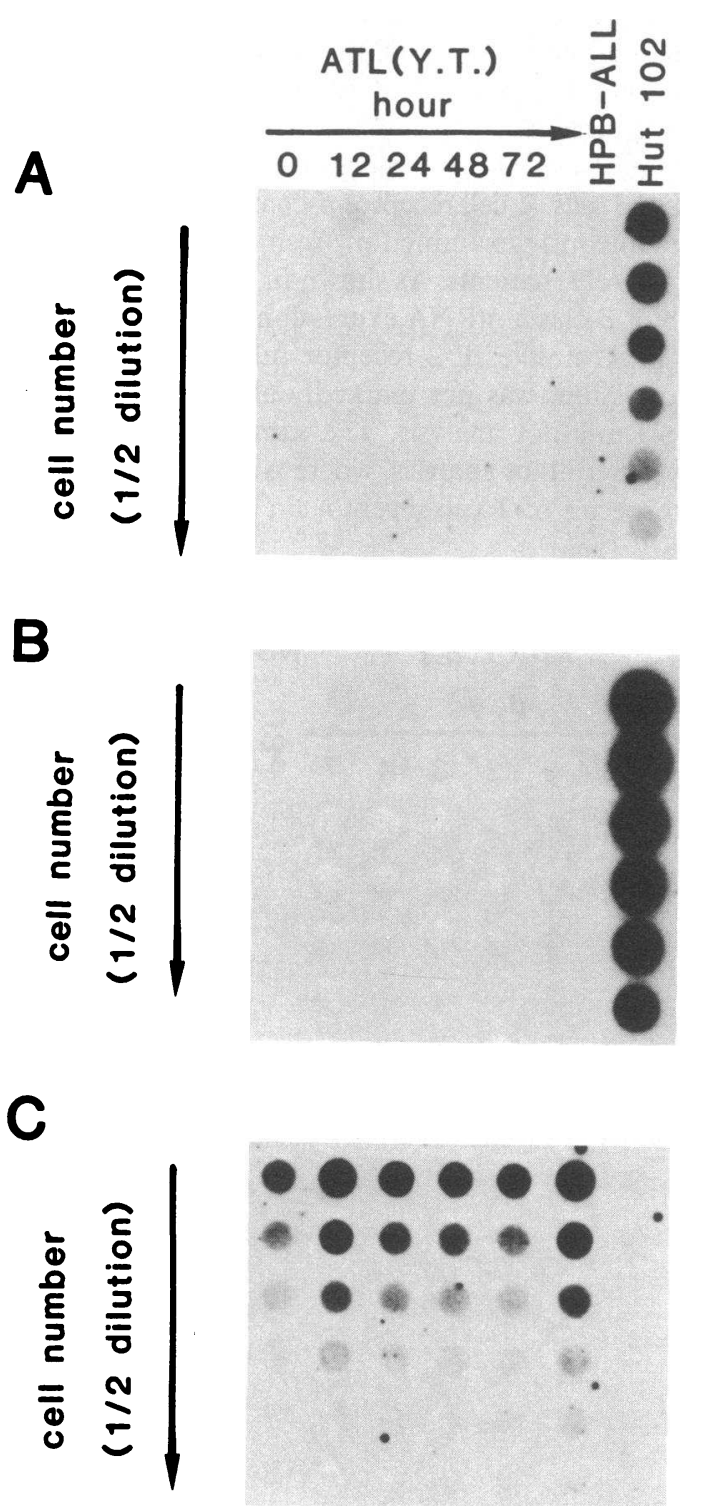

Figure 4. Expression of IL-2 receptor mRNA, HTLV-I viral RNA, and $\mathrm{T}$ cell receptor $\beta$-chain mRNA in case Y.T. Cytoplasmic dot analyses of IL-2 receptor mRNA $(A)$, HTLV-I viral RNA $(B)$, and T cell receptor $\beta$-chain mRNA $(C)$ expression before and after shortterm cultures are shown. The number of cells from which cytoplasmic extracts were derived and the manner of sample dilutions are the same as described in Fig. 2.

different sizes, 1.3 and $1.0 \mathrm{~kb}$, as reported previously (26). In contrast, about $2^{3}$ - and 2 to $2^{2}$-fold increases of $T$ cell receptor $\beta$-chain mRNA were noted after $1-d$ culture in cases Y.S. and Y.T., respectively (Figs. $3 C$ and $4 C$ ). However, the increase of IL-2 receptor mRNA was more than $2^{5}$-fold in these two cases and Northern blot analysis showed no increase of $T$ cell receptor $\beta$-chain mRNA in case Y.S. (Fig. $5 C$ ). Furthermore, leukemic cells from case Y.T. expressed relatively abundant $T$ cell receptor $\beta$-chain mRNA though the expression of IL-2 receptor mRNA and viral RNA was slight.

Effect of cycloheximide on the expression of $I L-2$ receptor $m R N A$, viral $R N A$, and $T$ cell receptor $\beta$-chain $m R N A$. We examined the effects of cycloheximide, a protein synthesis in- hibitor, on the expression of IL-2 receptor mRNA, HTLV-I viral RNA and T cell receptor $\beta$-chain mRNA in case M.S. When $10 \mu \mathrm{g} / \mathrm{ml}$ of cycloheximide was added at the beginning of the culture, such increases in IL-2 receptor mRNA and HTLV-I viral RNA expression as seen in the culture without cycloheximide were not observed (Figs. $6 A$ and $B$ ). In contrast, the amount of $T$ cell receptor $\beta$-chain mRNA rather increased by the addition of cycloheximide (Fig. $6 \mathrm{C}$ ). However, such an inhibitory effect of cycloheximide on the IL-2 receptor mRNA and HTLV-I viral RNA expression was no longer observed when it was added $24 \mathrm{~h}$ after the initiation of the culture (Figs. $6 A$ and $B$ ).

Expression of other cellular genes in fresh and cultured leukemic cells. We also studied the expression of other cellular genes ( $\beta$-actin, IL-2, c-myc, HPRT, and rRNA) in relation to the HTLV-I viral RNA expression. Although fresh leukemic cells expressed much more $\beta$-actin mRNA than IL- 2 receptor mRNA, the kinetics of $\beta$-actin mRNA expression during

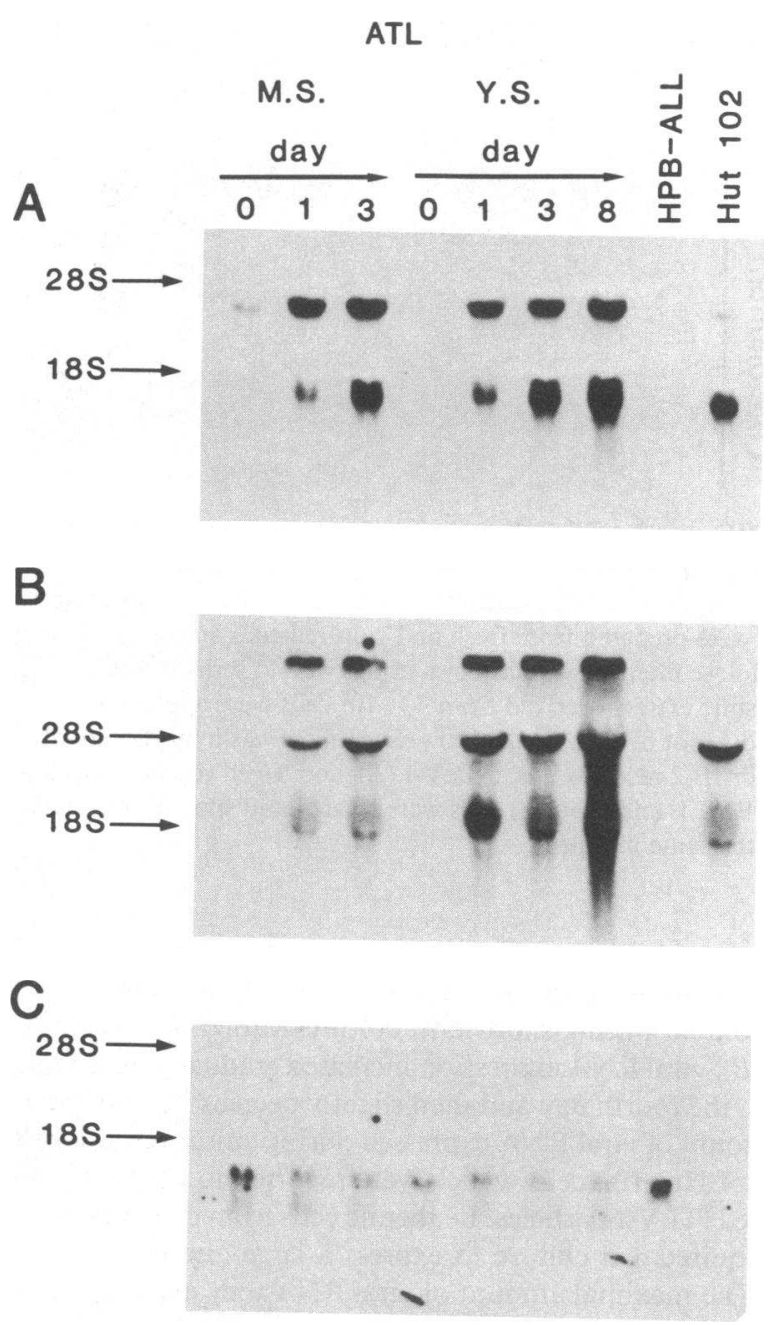

Figure 5. Northern blot analyses of IL-2 receptor mRNA, HTLV-I viral RNA and T cell receptor $\beta$-chain mRNA expression in cases M.S. and Y.S. The total RNA was extracted from leukemic cells harvested on the indicated day, HPB-ALL and Hut 102 cell line cells. Total RNA $(20 \mu \mathrm{g})$ was loaded, electrophoresed, transferred to a nitrocellulose filter and hybridized with probes for IL-2 receptor $(A)$, HTLV-I virus $(B)$ and T cell receptor $\beta$-chain $(C)$. 


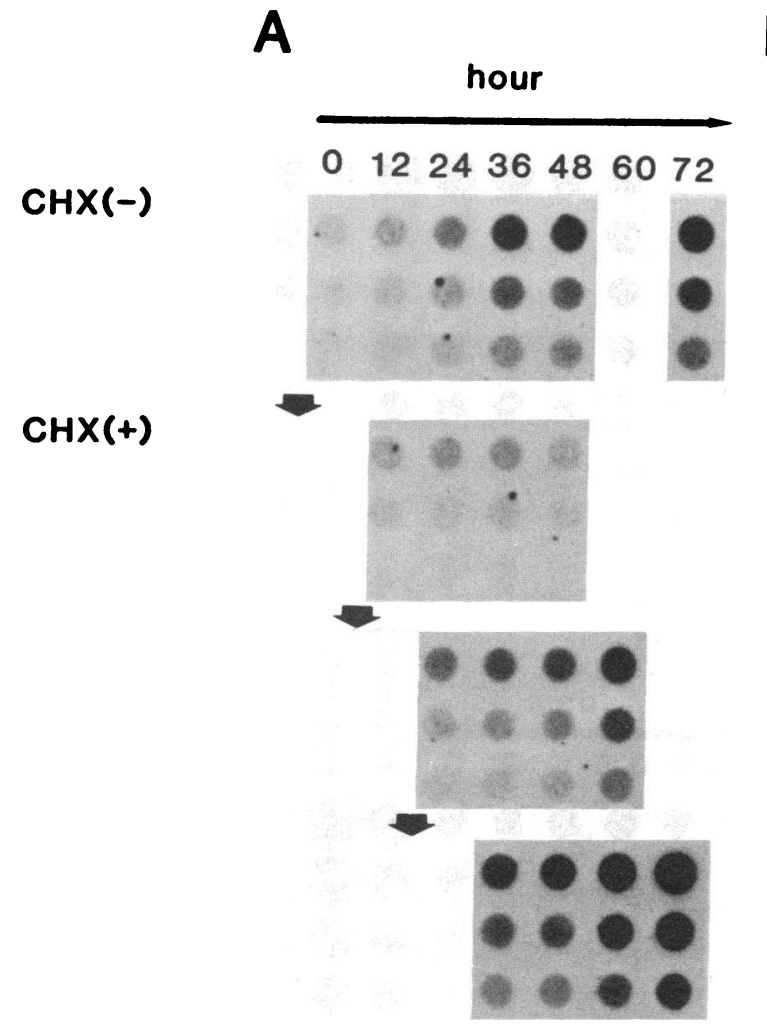

Figure 6. Effect of cycloheximide on the expression of IL-2 receptor mRNA, HTLV-I viral RNA, and T cell receptor $\beta$-chain mRNA after short-term cultures in case M.S. Cycloheximide $(10 \mu \mathrm{g} / \mathrm{ml})$ was added at $0 \mathrm{~h}$ (upper middle), $12 \mathrm{~h}$ (lower middle), and $24 \mathrm{~h}$ (bottom) after the beginning of the culture as indicated by thick arrows. The cells were harvested at the indicated time, and then cytoplasmic extracts were prepared from these cell samples and spotted onto nitrocellulose filters in vertical rows using twofold serial dilutions. As con-

short-term cultures was similar to that of IL-2 receptor mRNA and viral RNA expression especially in the cases in which IL-2 receptor mRNA and viral RNA expression was markedly enhanced during short-term cultures as in cases M.S. and Y.S. (Figs. $7 A$ and $B$ ). In other cases in which expression of IL-2 receptor mRNA and viral RNA was slight even after shortterm cultures the increase of $\beta$-actin mRNA was less than that of IL-2 receptor mRNA or viral RNA (less than twofold) (Fig. $7 \mathrm{C}$ ). Furthermore, the addition of cycloheximide at the beginning of or $12 \mathrm{~h}$ after the cultures inhibited the increase of $\beta$-actin mRNA as well as IL-2 receptor mRNA and viral RNA. In contrast, the addition of cycloheximide at $24 \mathrm{~h}$ of cultures inhibited the increase of $\beta$-actin mRNA but not IL-2 receptor mRNA or viral RNA (Fig. $7 \mathrm{D}$ ).

The expression of IL-2 mRNA (Fig. $8 \mathrm{~A}$ ) and HPRT mRNA (data not shown) was hardly detectable throughout short-term cultures in every case. The expression of c-myc mRNA (Fig. $8 \mathrm{~B}$ ) was also hardly detectable in every case except for two cases. In one case (case M.S.) the expression of c-myc mRNA was maximal on the fourth and fifth day of culture when the expression of IL-2 receptor mRNA and viral RNA was also maximal (Fig. $8 \mathrm{~B}$, left). In another case (case S.Ya.) in which expression of IL-2 receptor $m R N A$ and viral RNA was similar to that of case Y.T. (the data are not shown in figures), c-myc mRNA was expressed maximally in fresh
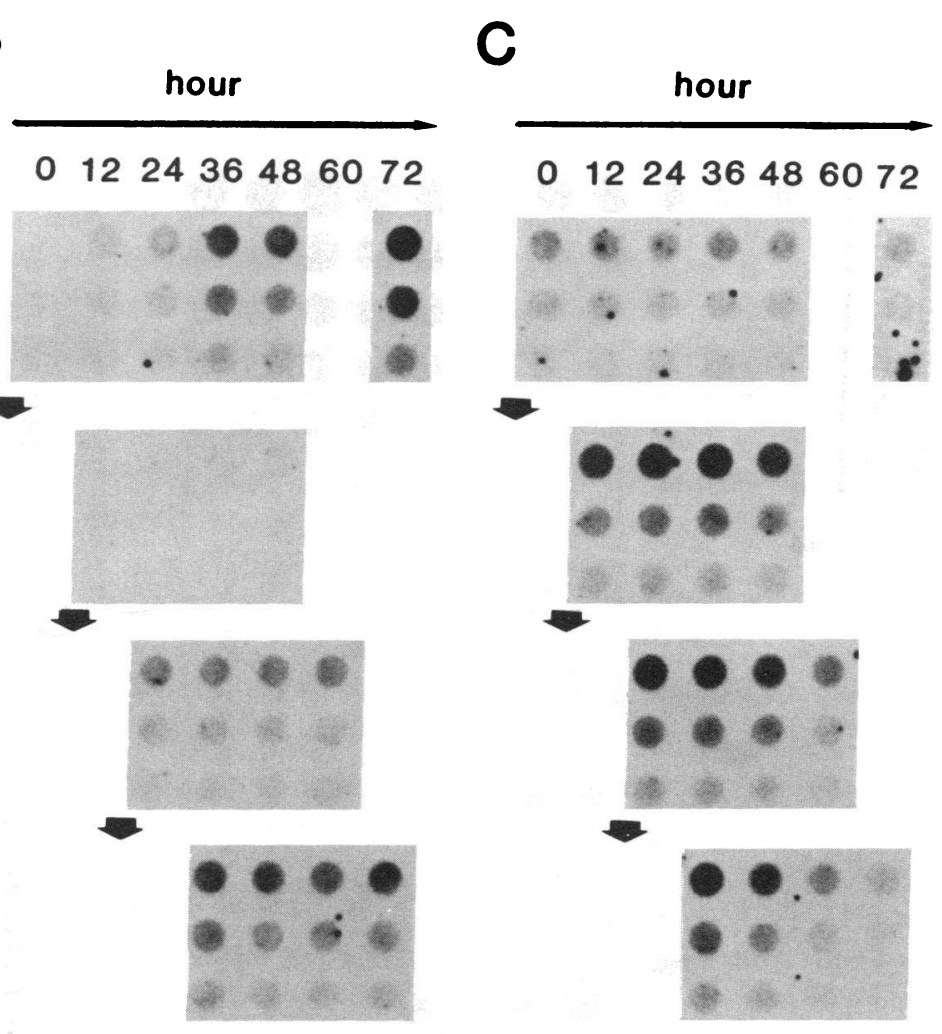

trols, fresh leukemic cells and leukemic cells cultured for the indicated time without cycloheximide were treated and spotted onto nitrocellulose filters in the same manner (top). Cytoplasmic extracts derived from $4 \times 10^{5}$ cells were applied to the uppermost spot of each vertical row. The expression of IL-2 receptor mRNA $(A)$, HTLV-I viral RNA $(B)$, and T cell receptor $\beta$-chain mRNA $(C)$ was analyzed.

leukemic cells and then decreased (data not shown). When the amount of rRNA was assessed as an indicator of the amount of total RNA applied to each dot, no increase of rRNA comparable to that of IL-2 receptor mRNA or viral RNA was observed during cultures (Fig. $8 \mathrm{C}$ ).

\section{Discussion}

As increasing evidence has demonstrated high homology or structural similarities between some oncogene products and cell growth factors or their receptors (43-46), the studies focusing on the involvement of cell growth factors or their receptors in the oncogenesis have become increasingly important for clarifying the mechanism of the oncogenesis. However, the number of papers reporting the abnormal expression of cell growth factor receptors in the human neoplastic cells is so far limited. The overexpression of the surface epidermal growth factor receptor was reported in primary human squamous cell carcinomas and primary human brain tumors of glial origin, as well as human squamous carcinoma cell lines. Such overexpression in human squamous carcinoma cell lines and human glial tumors was considered to be the result of gene amplification (47-51). In the previous reports (15-18) we have shown the spontaneous (without stimulation) and continuous expression (constitutive expression) of IL-2 receptors in leuke- 


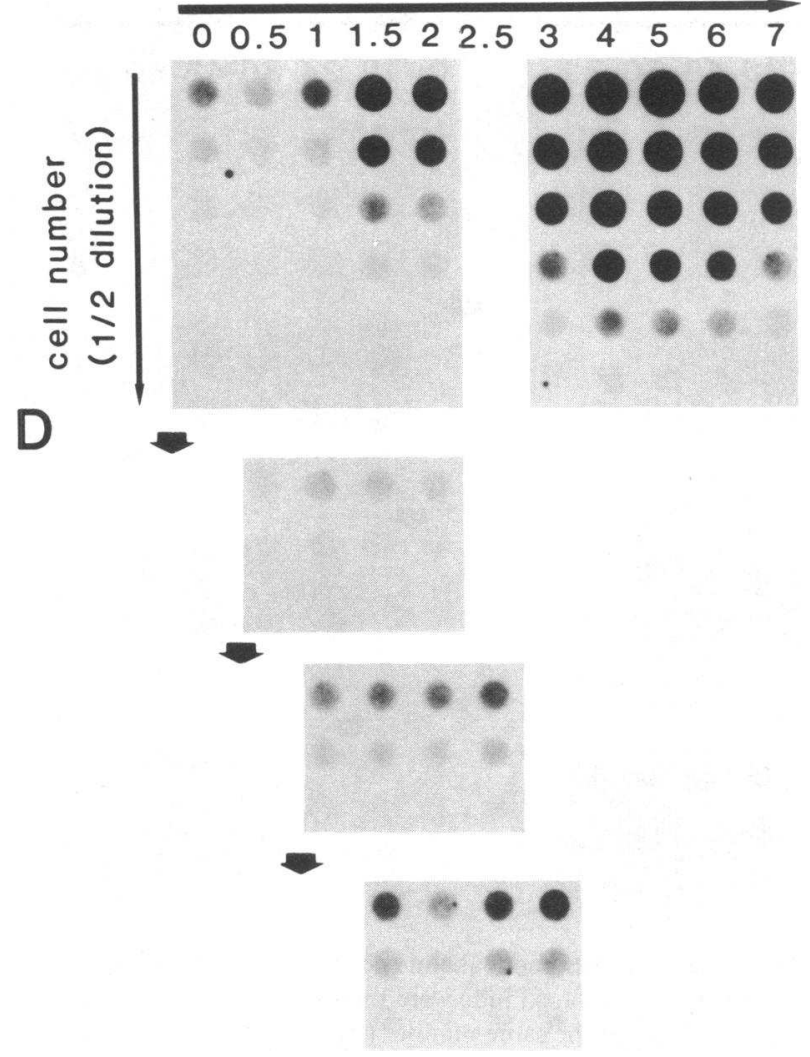

Figure 7. Expression of $\beta$-actin mRNA in cases M.S., Y.S., and Y.T., and the effect of cycloheximide on it in case M.S. Cytoplasmic dot analyses of $\beta$-actin mRNA expression before and after short-term cultures in case M.S. $(A)$, Y.S. $(B)$, and Y.T. $(C)$, and the expression of $\beta$-actin mRNA in the presence of cycloheximide $(D)$ from $0 \mathrm{~h}$

mic cells from ATL patients. However, the present study found no obvious amplification or gross rearrangement of the IL-2 receptor gene in Southern blot hybridization analysis of leukemic cell DNA from seven ATL patients. Thus, it does not appear that abnormalities of the IL-2 receptor gene such as amplification or gross rearrangement are responsible for the constitutive expression of IL-2 receptors in ATL leukemic cells. Furthermore, the analysis of HTLV-I proviral DNA integration sites excluded the possibility of the IL-2 receptor gene activation by cis insertion of retroviral promotor (or enhancer) sequences (52). Thus, it is speculated that the abnormal expression of IL-2 receptors in ATL leukemic cells is caused by mechanisms different from gene abnormalities or the promotor (or enhancer) insertion model.

In the present study, we showed that IL-2 receptor mRNA expression and HTLV-I viral RNA expression were concomitantly enhanced in the leukemic cells from ATL patients during short-term cultures, whereas other cellular genes, except for the $\beta$-actin gene, did not increase to the same extent. Although monoclonal HTLV-I proviral DNA integration was demonstrated in leukemic cells, HTLV-I viral RNA expression was not detected in fresh leukemic cells from nine ATL patients by cytoplasmic dot hybridization or Northern hybridization, which is consistent with other reports $(22,23)$. These

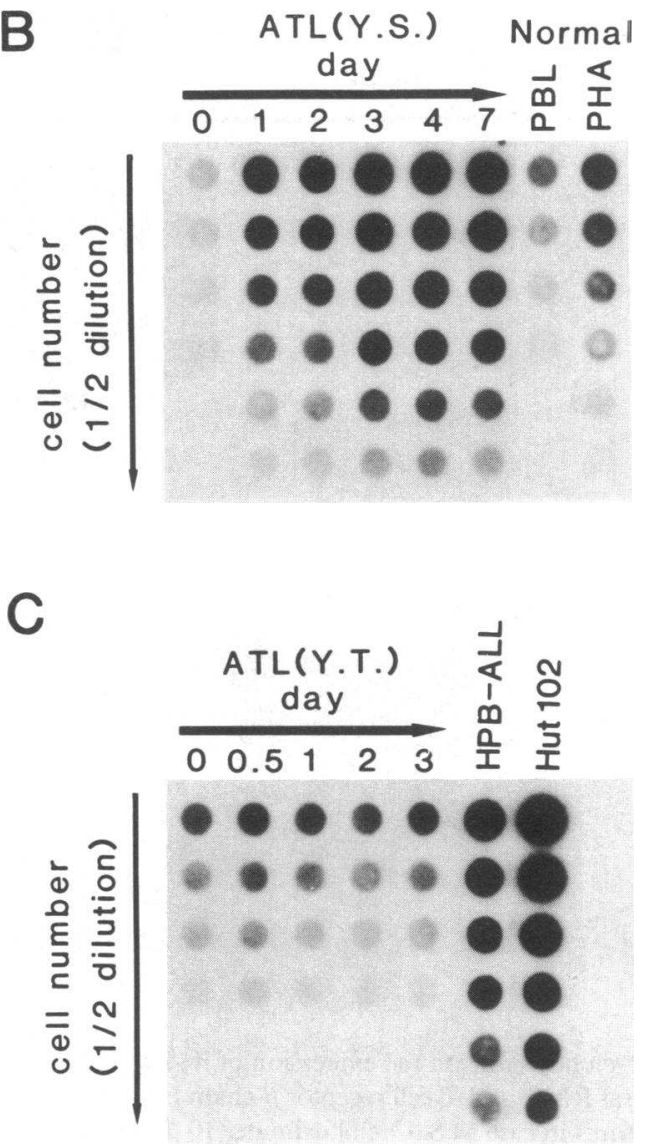

(top), $12 \mathrm{~h}$ (middle) or $24 \mathrm{~h}$ (bottom) after the initiation of the cultures (indicated by thick arrows) in case M.S. are shown. The number of cells from which cytoplasmic extracts were derived and the manner of sample dilutions are the same as described in Figs. 2 and 5.

findings are similar to the absence of expression of bovine leukemia virus, a member of the HTLV family, in cells of fully developed bovine tumors (53). In contrast, IL-2 receptor expression was detected in fresh leukemic cells from most patients at both IL-2 receptor protein and mRNA levels although the expression was weak or mild. Once the leukemic cells were isolated from patients and cultured for a short period, both HTLV-I RNA and IL-2 receptor mRNA expression concurrently increased. As shown in case Y.T. in which HTLV-I viral RNA and IL-2 receptor mRNA expression was low in both fresh and cultured cells, and in cases M.S. and Y.S. where both HTLV-I viral RNA and IL-2 receptor mRNA were strongly expressed, the degrees of their expression were well correlated with each other in every case. In addition, the expression of both IL-2 receptor mRNA and HTLV-I viral RNA concomitantly increased in leukemic cells cultured for up to $7 \mathrm{~d}$ and the patterns of their cytoplasmic dot hybridization studies were quite similar in each case.

Demonstration of IL-2 receptor expression in leukemic cells from ATL patients $(15,18)$, HTLV-I-infected human cell lines (19), rat T cell lines (20) and STLV-infected cell lines (21) strongly suggested a close association between HTLV-I infection and IL-2 receptor expression. However, studies to clarify their association and its mechanism in leukemic cells from 

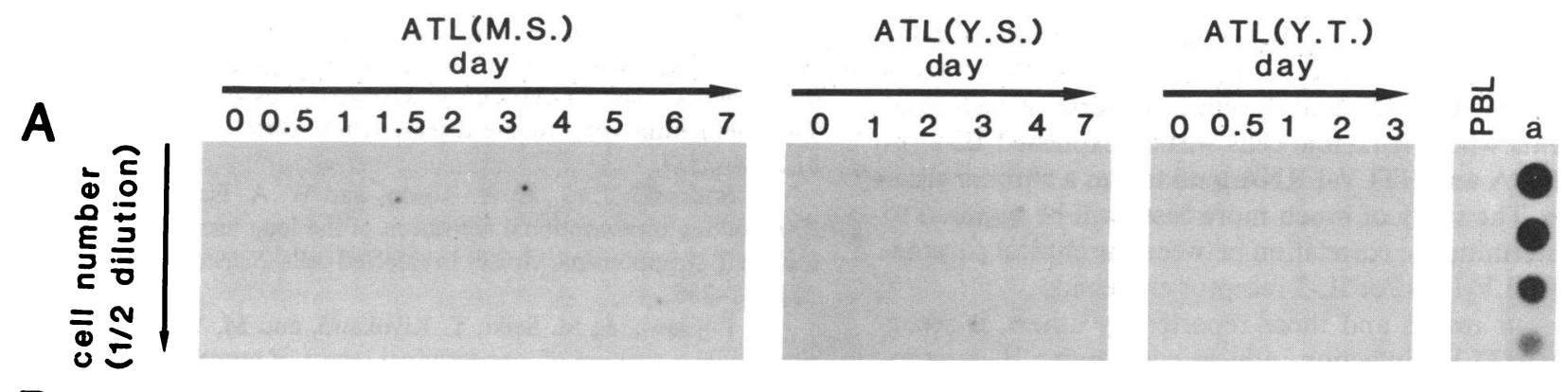

B
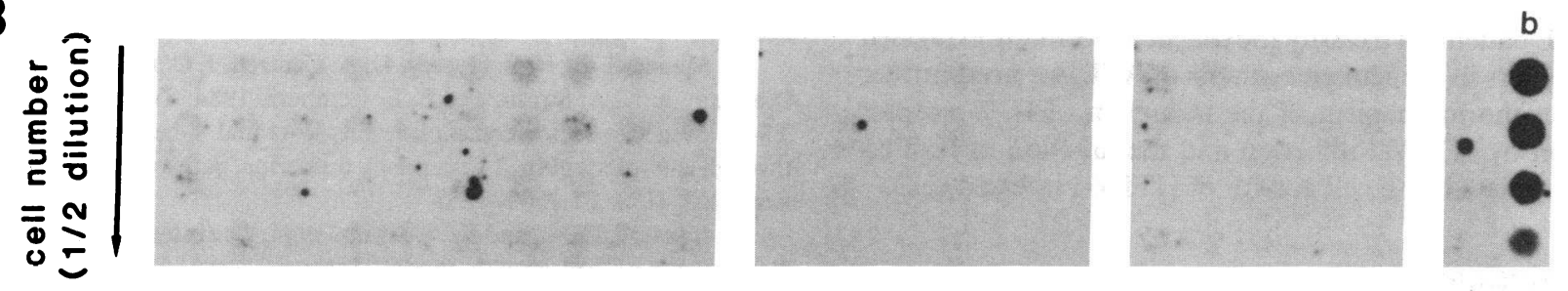

C
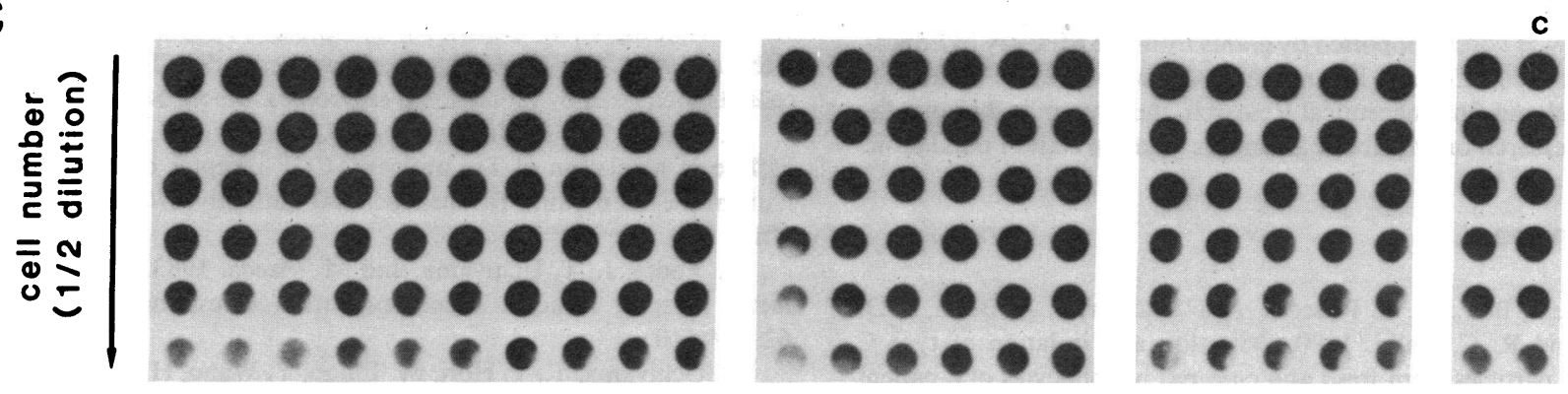

Figure 8. Expression of IL-2 mRNA, c-myc mRNA, and rRNA in cases M.S., Y.S., and Y.T. Cytoplasmic dot analyses of IL-2 mRNA $(A)$, c-myc mRNA $(B)$, and rRNA $(C)$ expression in cases M.S. (left), Y.S. (middle), and Y.T. (right) are shown. The number of cells from which cytoplasmic extracts were derived and the manner of sample dilutions are as described in Fig. 2. As controls, normal peripheral blood mononuclear cells without culture (indicated as PBL), or cultured with PHA-P and 12-O-tetradecanoylphorbol-13-acetate (TPA) for $20 \mathrm{~h}(a)$, HL-60 cells $(b)$, and normal PHA-activated lymphocytes (c) were treated and spotted onto nitrocellulose filters in the same manner.

the $p X$ gene into Jurkat cells. However, we failed to detect IL-2 mRNA expression in short-term cultured leukemic cells. One explanation for this discrepancy is that the expression of IL-2 mRNA, if it occurred, was too weak to be detected in our study. Alternatively; IL-2 mRNA expression may be easily induced by $p X$ product in a particular cell line (Jurkat), in which lectins and/or phorbol esters also induce IL-2 production. In either case, our present results do not exclude the possibility that the autocrine mechanism mediated by IL-2 and IL-2 receptor system acts in a certain stage of the leukemogenesis of ATL or somewhere in vivo in ATL patients where leukemic cells are proliferating.

The increase of $\beta$-actin mRNA during short-term cultures in some cases may be caused by $p X$ product, which may directly activate the transcription of several cellular genes including the IL- 2 receptor and $\beta$-actin genes. However, another explanation is that the increase of $\beta$-actin mRNA is secondary to the activation of the viral and the IL-2 receptor genes by $p X$ product. It may be reflected in the fact that the addition of cycloheximide $24 \mathrm{~h}$ after the initiation of the culture inhibited the increase of $\beta$-actin mRNA but not those of IL- 2 receptor and viral RNA. In any case, we can not exclude the possibility that $p X$ product activates several cellular genes, one of which is the IL-2 receptor gene.

Although we studied a limited number of cases, there 
seems to be some correlation between the expression of both IL-2 receptor mRNA and HTLV-I RNA during short-term cultures of leukemic cells and the clinical course of each case. The patients whose leukemic cells weakly expressed IL-2 receptor mRNA and HTLV-I RNA tend to run a chronic clinical course. The study of much more cases will be required to exactly determine the correlation between the clinical parameters and HTLV-I and/or IL-2 receptor expression.

From our results and those reported by others, it seems likely that HTLV-I infection induces constitutive IL-2 receptor expression in not only cell line cells but also leukemic cells from ATL patients. To clarify the role of abnormally expressed IL-2 receptors in the leukemogenesis of ATL, we need further studies on the mechanism of the induction of IL-2 receptor expression by HTLV-I infection and the function of IL-2 receptor associated with cell growth of HTLV-I infected cells.

\section{Acknowledgments}

This work was partly supported by grants from the Ministry of Education, Science and Culture, Japan, the Mochida Memorial Foundation for Medical and Pharmaceutical Research, the Yamanouchi Foundation for Research on Metabolic Disorders, and the Naito Foundation.

\section{References}

1. Poiesz, B. J., F. W. Ruscetti, A. F. Gazdar, P. A. Bunn, J. D. Minna, and R. C. Gallo. 1980. Detection and isolation of type C retrovirus particles from fresh and cultured lymphocytes of a patient with cutaneous T-cell lymphoma. Proc. Natl. Acad. Sci. USA. 77:7415-7419.

2. Popovic, M., M. S. Reitz, Jr., M. G. Sarngadharan, M. RobertGuroff, V. S. Kalyanaraman, Y. Nakao, I. Miyoshi, J. Minowada, M. Yoshida, Y. Ito, and R. C. Gallo. 1982. The virus of Japanese adult T-cell leukaemia is a member of the human T-cell leukaemia virus group. Nature (Lond.). 300:63-66.

3. Watanabe, T., M. Seiki, and M. Yoshida. 1984. HTLV type I (U. S. isolate) and ATLV (Japanese isolate) are the same species of human retrovirus. Virology. 133:238-241.

4. Hinuma, Y., K. Nagata, M. Hanaoka, M. Nakai, T. Matsumoto, K. Kinoshita, S. Shirakawa, and I. Miyoshi. 1.981. Adult T-cell leukemia: antigen in an ATL cell line and detection of antibodies to the antigen in human sera. Proc. Natl. Acad. Sci. USA. 78:6476-6480.

5. Yoshida, M., I. Miyoshi, and Y. Hinuma. 1982. Isolation and characterization of retrovirus from cell lines of human adult T-cell leukemia and its implication in the disease. Proc. Natl. Acad. Sci. USA. 79:2031-2035.

6. Uchiyama, T., J. Yodoi, K. Sagawa, K. Takatsuki, and H. Uchino. 1977. Adult T-cell leukemia: clinical and hematologic features of 16 cases. Blood. 50:481-492.

7. Robert-Guroff, M., Y. Nakao, K. Notake, Y. Ito, A. Sliski, and R. C. Gallo. 1982. Natural antibodies to human retrovirus HTLV in a cluster of Japanese patients with adult T cell leukemia. Science (Wash. DC). 215:975-978.

8. Hinuma, Y., H. Komoda, T. Chosa, T. Kondo, M. Kohakura, T. Takenaka, M. Kikuchi, M. Ichimaru, K. Yunoki, I. Sato, R. Matsuo, Y. Takiuchi, H. Uchino, and M. Hanaoka. 1982. Antibodies to adult T-cell leukemia-virus-associated antigen (ATLA) in sera from patients with ATL and controls in Japan: a nation-wide sero-epidemiologic study. Int. J. Cancer. 29:631-635.

9. Blattner, W. A., V. S. Kalyanaraman, M. Robert-Guroff, T. A. Lister, D. A. G. Galton, P. S. Sarin, M. H. Crawford, D. Catovsky, M. Greaves, and R. C. Gallo. 1982. The human type-C retrovirus, HTLV, in blacks from the Caribbean region, and relationship to adult T-cell leukemia/lymphoma. Int. J. Cancer. 30:257-264.
10. Yoshida, M., M. Seiki, K. Yamaguchi, and K. Takatsuki. 1984. Monoclonal integration of human T-cell leukemia provirus in all primary tumors of adult T-cell leukemia suggests causative role of human T-cell leukemia virus in the disease. Proc. Natl. Acad. Sci. USA. 81:2534-2537.

11. Sodroski, J. G., C. A. Rosen, and W. A. Haseltine. 1984. Trans-acting transcriptional activation of the long terminal repeat of human T lymphotropic viruses in infected cells. Science (Wash. DC). 225:381-385.

12. Fujisawa, J., M. Seiki, T. Kiyokawa, and M. Yoshida. 1985. Functional activation of long terminal repeat of human T-cell leukemia virus by trans-acting factor. Proc. Natl. Acad. Sci. USA. 82:22772281.

13. Meuer, S. C., R. E. Hussey, D. A. Cantrell, J. C. Hodgdon, S. F. Schlossman, K. A. Smith, and E. L. Reinherz. 1984. Triggering of the $\mathrm{T} 3-\mathrm{Ti}$ antigen-receptor complex results in clonal $\mathrm{T}$-cell proliferation through an interleukin 2-dependent autocrine pathway. Proc. Natl. Acad. Sci. USA. 81:1509-1513.

14. Cantrell, D. A., and K. A. Smith. 1984, The interleukin-2 T-cell system: A new cell growth model. Science (Wash. DC). 224:13121316.

15. Hattori, T., T. Uchiyama, T. Toibana, K. Takatsuki, and H. Uchino. 1981. Surface phenotype of Japanese adult T-cell leukemia cells characterized by monoclonal antibodies. Blood. 58:645-647.

16. Tsudo, M., T. Uchiyama, H. Uchino, and J. Yodoi. 1983. Failure of regulation of Tac antigen/TCGF receptor on adult T-cell leukemia cells by anti-Tac monoclonal antibody. Blood. 61:10141016.

17. Yodoi, J., T. Uchiyama, and M. Maeda. 1983. T cell growth factor receptor in adult $\mathrm{T}$ cell leukemia (correspondence). Blood. 62:509-510.

18. Uchiyama, T., T. Hori, M. Tsudo, Y. Wano, H. Umadome, S. Tamori, J. Yodoi, M. Maeda, H. Sawami, and H. Uchino. 1985. Interleukin-2 receptor (Tac antigen) expressed on adult $\mathrm{T}$ cell leukemia cells. J. Clin. Invest. 76:446-453.

19. Depper, J. M., W. J. Leonard, M. Kronke, T. A. Waldmann, and W. C. Greene. 1984. Augmented T cell growth factor receptor expression in HTLV-I-infected human leukemic T cells. J. Immunol. 133:1691-1695.

20. Yodoi, J., M. Okada, Y. Tagaya, K. Teshigawara, K. Fukui, N. Ishida, K. Ikuta, M. Maeda, T. Honjo, H. Osawa, T. Diamanstein, M. Tateno, and T. Yoshiki. 1985. Rat lymphoid cell lines producing human T cell leukemia virus. II. Constitutive expression of rat interleukin 2 receptor. J. Exp. Med. 161:924-934.

21. Tsujimoto, H., A. Komuro, K. Iijima, J. Miyamoto, K. Ishikawa, and M. Hayami. 1985. Isolation of simian retroviruses closely related to human T-cell leukemia virus by establishment of lymphoid cell lines from various non-human primates. Int. J. Cancer. 35:377384.

22. Hinuma, Y., Y. Gotoh, K. Sugamura, K. Nagata, T. Goto, M. Nakai, N. Kamada, T. Matsumoto, and K. Kinoshita. 1982. A retrovirus associated with human adult T-cell leukemia: in vitro activation. Gann. 73:341-344.

23. Clarke, M. F., C. D. Trainor, D. L. Mann, R. C. Gallo, and M. S. Reitz. 1984. Methylation of human T-cell leukemia virus proviral DNA and viral RNA expression in short- and long-term cultures of infected cells. Virology. 135:97-104.

24. Hahn, B., R. C. Gallo, G. Franchini, M. Popovic, T. Aoki, S. Z. Salahuddin, P. D. Markham, and F. Wong-Staal. 1984. Clonal selection of human T-cell leukemia virus-infected cells in vivo and in vitro. Mol. Biol. Med. 2:29-36.

25. Maeda, M., A. Shimizu, K. Ikuta, H. Okamoto, M. Kashihara, T. Uchiyama, T. Honjo, and J. Yodoi. 1985. Origin of human T-lymphotrophic virus I-positive $T$ cell lines in adult T cell leukemia. Analysis of T cell receptor gene rearrangement. J. Exp. Med. 162:21692174.

26. Jarrett, R. F., H. Mitsuya, D. L. Mann, J. Cossman, S. Broder, and M. S. Reitz. 1986. Configuration and expression of the $T$ cell 
receptor $\beta$-chain in human T-lymphotrophic virus I-infected cells. $J$. Exp. Med. 163:383-399.

27. Uchiyama, T., S. Broder, and T. A. Waldmann. 1981. A monoclonal antibody (anti-Tac) reactive with activated and functionally mature human T cells. I. Production of anti-Tac monoclonal antibody and distribution of Tac (+) cells. J. Immunol. 126:1393-1397.

28. Uchiyama, T., D. L. Nelson, T. A. Fleisher, and T. A. Waldmann. 1981. A monoclonal antibody (anti-Tac) reactive with activated and functionally mature human $T$ cells. II. Expression of Tac antigen on activated cytotoxic killer $T$ cells, suppressor cells, and on one of two types of helper T cells. J. Immunol. 126:1398-1403.

29. White, B. A., and F. C. Bancroft. 1982. Cytoplasmic dot hybridization. Simple analysis of relative mRNA levels in multiple small cell or tissue samples. J. Biol. Chem. 257:8569-8572.

30. Honjo, T., M. Obata, Y. Yamawaki-Kataoka, T. Kataoka, T. Kawakami, N. Takahashi, and Y. Mano. 1979. Cloning and complete nucleotide sequence of mouse immunoglobulin $\gamma 1$ chain gene. Cell. 18:559-568.

31. Southern, E. M. 1975. Detection of specific sequences among DNA fragments separated by gel electrophoresis. J. Mol. Biol. 98:503-517.

32. Chirgwin, J. M., A. E. Przybyla, R. J. MacDonald, and W. J. Rutter. 1979. Isolation of biologically active ribonucleic acid from sources enriched in ribonuclease. Biochemistry. 18:5294-5299.

33. Glisin, V., R. Crkvenjakov, and C. Byus. 1974. Ribonucleic acid isolated by cesium chloride centrifugation. Biochemistry. 13:2633-2637.

34. Thomas, P. S. 1980. Hybridization of denatured RNA and small DNA fragments transferred to nitrocellulose. Proc. Natl. Acad. Sci. USA. 77:5201-5205.

35. Nikaido, T., A. Shimizu, N. Ishida, H. Sabe, K. Teshigawara, M. Maeda, T. Uchiyama, J. Yodoi, and T. Honjo. 1984. Molecular cloning of cDNA encoding human interleukin-2 receptor. Nature (Lond.). 311:631-635.

36. Seiki, M., S. Hattori, Y. Hirayama, and M. Yoshida. 1983. Human adult T-cell leukemia virus: complete nucleotide sequence of the provirus genome integrated in leukemia cell DNA. Proc. Natl. Acad. Sci. USA. 80:3618-3622.

37. Ikuta, K., T. Ogura, A. Shimizu, and T. Honjo. 1985. Low frequency of somatic mutation in $\beta$-chain variable region genes of human T-cell receptors. Proc. Natl. Acad. Sci. USA. 82:7701-7705.

38. Taniguchi, T., H. Matsui, T. Fujita, C. Takaoka, N. Kashima, R. Yoshimoto, and J. Hamuro. 1983. Structure and expression of a cloned cDNA for human interleukin-2. Nature (Lond.). 302:305-310.

39. Brennand, J., A. C. Chinault, D. S. Konecki, D. W. Melton, and C. T. Caskey. 1982. Cloned cDNA sequences of the hypoxanthine/guanine phosphoribosyltransferase gene from a mouse neuroblastoma cell line found to have amplified genomic sequences. Proc. Natl. Acad. Sci. USA. 79:1950-1954.

40. Maniatis, T., A. Jeffrey, and D. G. Kleid. 1975. Nucleotide sequence of the rightward operator of phage $\lambda$. Proc. Natl. Acad. Sci. USA. 72:1184-1188.

41. Leonard, W. J., J. M. Depper, G. R. Crabtree, S. Rudikoff, J. Pumphrey, R. J. Robb, M. Kronke, P. B. Svetlik, N. J. Peffer, T. A. Waldmann, and W. C. Greene. 1984. Molecular cloning and expression of cDNAs for the human interleukin-2 receptor. Nature (Lond.). 311:626-631.

42. Seiki, M., A. Hikikoshi, T. Taniguchi, and M. Yoshida. 1985. Expression of the $p X$ gene of HTLV-I: general splicing mechanism in the HTLV family. Science (Wash. DC). 228:1532-1534.
43. Waterfield, M. D., G. T. Scrace, N. Whittle, P. Stroobant, A. Johnsson, A. Wasteson, B. Westermark, C.-H. Heldin, J. S. Huang, and T. F. Deuel. 1983. Platelet-derived growth factor is structurally related to the putative transforming protein $\mathrm{p} 28^{\mathrm{sis}}$ of simian sarcoma virus. Nature (Lond.). 304:35-39.

44. Doolittle, R. F., M. W. Hunkapiller, L. E. Hood, S. G. Devare, K. C. Robbins, S. A. Aaronson, and H. N. Antoniades. 1983. Simian sarcoma virus onc gene, v-sis, is derived from the gene (or genes) encoding a platelet-derived growth factor. Science (Wash. DC). 221:275-277.

45. Downward, J., Y. Yarden, E. Mayes, G. Scrace, N. Totty, P. Stockwell, A. Ullich, J. Schlessinger, and M. D. Waterfield. 1984. Close similarity of epidermal growth factor receptor and v-erb-B oncogene protein sequences. Nature (Lond.). 307:521-527.

46. Sherr, C. J., C. W. Rettenmier, R. Sacca, M. F. Roussel, A. T. Look, and E. R. Stanley. 1985. The c-fms proto-oncogene product is related to the receptor for the mononuclear phagocyte growth factor, CSF-1. Cell. 41:665-676.

47. Merlino, G. T., Y-H. Xu, S. Ishii, A. J. L. Clark, K. Semba, K. Toyoshima, T. Yamamoto, and I. Pastan. 1984. Amplification and enhanced expression of the epidermal growth factor receptor gene in A431 human carcinoma cells. Science (Wash. DC). 224:417-419.

48. Ullrich, A., L. Coussens, J. S. Hayflick, T. J. Dull, A. Gray, A. W. Tam, J. Lee, Y. Yarden, T. A. Libermann, J. Schlessinger, J. Downward, E. L. V. Mayes, N. Whittle, M. D. Waterfield, and P. H. Seeburg. 1984. Human epidermal growth factor receptor cDNA sequence and aberrant expression of the amplified gene in A431 epidermoid carcinoma cells. Nature (Lond.). 309:418-425.

49. Lin, C. R., W. S. Chen, W. Kruiger, L. S. Stolarsky, W. Weber, R. M. Evans, I. M. Verma, G. N. Gill, and M. G. Rosenfeld. 1984. Expression cloning of human EGF receptor complementary DNA: gene amplification and three related messenger RNA products in A431 cells. Science (Wash. DC). 224:843-848.

50. Liebermann, T. A., H. R. Nusbaum, N. Razon, R. Kris, I. Lax, H. Soreq, N. Whittle, M. D. Waterfield, A. Ullrich, and J. Schlessinger. 1985. Amplification, enhanced expression and possible rearrangement of EGF receptor gene in primary human brain tumours of glial origin. Nature (Lond.). 313:144-147.

51. Yamamoto, T., N. Kamata, H. Kawano, S. Shimizu, T. Kuroki, K. Toyoshima, K. Rikimaru, N. Nomura, R. Ishizaki, I. Pastan, S. Gamou, and N. Shimizu. 1986. High incidence of amplification of the epidermal growth factor receptor gene in human squamous carcinoma cell lines. Cancer Res. 46:414-416.

52. Seiki, M., R. Eddy, T. B. Shows, and M. Yoshida. 1984. Nonspecific integration of the HTLV provirus genome into adult T-cell leukaemia cells. Nature (Lond.). 309:640-642.

53. Kettmann, R., J. Deschamps, Y. Cleuter, D. Couez, A. Burny, and G. Marbaix. 1982. Leukemogenesis by bovine leukemia virus. Proviral DNA integration and lack of RNA expression of viral long terminal repeat and $3^{\prime}$ proximate cellular sequences. Proc. Natl. Acad. Sci. USA. 79:2465-2469.

54. Teshigawara, K., M. Maeda, K. Nishino, T. Nikaido, T. Uchiyama, M. Tsudo, Y. Wano, and J. Yodoi. 1985. Adult T cell leukemia cells produce a lymphokine that augments interleukn 2 receptor expression. J. Mol. Cell. Immunol. 2:17-22.

55. Inoue, J., M. Seiki, T. Taniguchi, S. Tsuru, and M. Yoshida. 1986. Induction of interleukin 2 receptor gene expression by $\mathrm{p} 40^{x}$ encoded by human T-cell leukemia virus type 1. EMBO (Eur. Mol. Biol. Org.) J. 5:2883-2888. 